\title{
Abnormal Urine Cytology
}

National Cancer Institute

\section{Source}

National Cancer Institute. Abnormal Urine Cytology. NCI Thesaurus. Code C4854.

A laboratory test result indicating abnormal cells found in the urine sample. 